\title{
Evaluation of the Teaching Practices of Physics and Chemistry Sciences for Teachers of Secondary Qualifying Moroccan School
}

\author{
CH. Rhezzal ${ }^{1, *}$, M. Ibrahimi ${ }^{1}$, D. Lamri ${ }^{2}$ \\ ${ }^{1}$ Laboratory of Optoelectronics, Physical Chemistry of Materials and Environment (LOPCME), Faculty of Sciences, Ibn Tofail \\ University, Morocco \\ ${ }^{2}$ Regional Center of Education and Training Rabat-Sale-Kenitra, Morocco
}

Received November 15, 2020; Revised February 18, 2021; Accepted March 12, 2021

\begin{abstract}
Cite This Paper in the following Citation Styles
(a): [1] CH. Rhezzal, M. Ibrahimi, D. Lamri, "Evaluation of the Teaching Practices of Physics and Chemistry Sciences for Teachers of Secondary Qualifying Moroccan School," Universal Journal of Educational Research, Vol. 9, No. 3, pp. 586 - 592, 2021. DOI: 10.13189/ujer.2021.090318.
\end{abstract}

(b): CH. Rhezzal, M. Ibrahimi, D. Lamri (2021). Evaluation of the Teaching Practices of Physics and Chemistry Sciences for Teachers of Secondary Qualifying Moroccan School. Universal Journal of Educational Research, 9(3), 586- 592. DOI: 10.13189/ujer.2021.090318.

Copyright $\bigcirc 2021$ by authors, all rights reserved. Authors agree that this article remains permanently open access under the terms of the Creative Commons Attribution License 4.0 International License

\begin{abstract}
Teaching practice is an action of the teachers and the students who are contributing together in the elaboration of knowledge in the classroom. This practice has an important scientific interest for school success, quality and efficiency of teaching. The objective of our work is to evaluate teaching practices in learning situations in order to ensure a good quality of teaching in Moroccan schools. An exploratory survey was conducted during the 2019-2020 about classroom practices for 50 qualified high school physical chemistry sciences teachers recruited from 10 public schools in Kenitra. The results of our study showed that the practices adopted by the teachers are numerous and their uses change from one teacher to another, and each practice has specific effects that allow the teacher to select effective and appropriate methods to achieve each effect, in order to regulate the learning of students, improve their levels and evolve the teaching and learning process. In fact the evaluation of teacher practices plays a very important role in detecting problems encountered by teachers during a teaching and learning situation.
\end{abstract}

Keywords Learning, Evaluation, Teaching Practices Physics and Chemistry

\section{Introduction}

In education sciences, research concerning the analysis of teaching and learning situations has developed since the 1950s in United States [1]. Firstly focused on the definition of a "good teacher" based on teachers' personality traits (Ibid.), this research then, during the 1960s and 1970s, attempted to determine the effectiveness of teaching practices based on students' academic performance [2].

Research on teaching practices is becoming more and more numerous and most important today. The main challenge of this research is to understand the modalities of teaching practices in the classroom, their organization, their functioning, and the processes involved, in order to understand their relationship with student learning.

Whether it is a question of teaching practice(s), teaching activity or teacher work, it is generally understood that these concepts refer to all tasks carried out by teachers in the presence or absence of students [3].

For Altet (2002), this "refers to a situated professional activity, oriented by the purposes, goals and norms of an occupational group. It translates into the implementation of the knowledge, processes and skills in action of a person in a professional situation" (p. 86) [4].

As for the term practical, it appears in 1256 according to Rey and Morvan, borrowed from the Christian Latin 
practice designating active life as opposed to contemplation. This term designates a habitual action, associated with a rule of action and aiming at concrete results. Teaching practice expresses in everyday language the habitual way of proceeding of this professional group. Thus, practice has a dual dimension: gestures and behaviors on one hand, and objectives, strategies and ideologies on the other hand, According to Beillerot. Clanet defines teaching practice as "all of activities deployed by a teacher in the context of his or her professional activity".

Finally, practice varies greatly from one teacher to another and even more so intra-individually, and it is more appropriate to speak of practices in the plural. [5]

Several research studies have addressed the study of teacher practice, particularly in terms of its variability.

Postlethwaite showed that nearly $70 \%$ of the variance corresponded to intra-teacher variability, compared to $30 \%$ for interteacher variability [6]. The research conducted by Crahay also supports this view, and the author concludes that teachers vary their teaching according to what they teach much more than they differ among themselves. This research thus shows that for the same situation, several teachers consider similar behaviors, whereas in different situations, a teacher would change his or her behavior more.

The practice is established in a professional situation. It consists of multiple dimensions. It is a situated professional activity, oriented by goals and standards. It translates knowledge, processes and skills into an individual's actions. Teaching practices concern all the interactions that can occur between teachers and actors of the educational system under the effect of a particular context. They are linked to professional activities that are situated and finalized and determined by psychosocial, cognitive, temporal, contextual, technical and interactive factors. They are thus characterized by "gestures, behaviors, language, actions, but also cognitive activities, ideologies, representations..."

Teaching practice is broadly defined. It is to be understood as "the totality of a teacher's professional practices: supervision of recess, teaching in partnership, participation on various boards, etc."[7]. In fact, teaching practice includes all the professional tasks related to the teaching profession and therefore includes the practice or act of teaching, related to the teacher's work in the classroom.

Moreover, at least two major visions of educational planning are possible in the research on them [8]. There are undeniable links between this technicist approach and the "process-product" current which, from a functionalist perspective, seeks to identify what works in the field according to Dessus and Wanlin. For Dessus, this prescriptive logic has the disadvantage of abusively theorizing educational facts without linking them to real situations, placing efficiency at the forefront [9].
Altet defines the teaching practice as the singular way of doing a person, his real, proper way of carrying out a professional activity: teaching. The practice is not only the set of observable acts, actions, reactions, but it includes the procedures of implementation of the activity in a given situation by a person, the choices, the decision making. [10] Other researchers in educational science, such as Barbier, define practice not as a way of doing things for a person but rather as a process of transforming one reality into another, requiring the intervention of a human operator (operative process). $\mathrm{He}$ is interested in the processes of accompaniment of a practice that he designates by "driving process" which includes "mental gestures" and "representational phenomena" and by "affective process" which includes "phenomena indissociably linked to the image of oneself, individual or collective"[11].

We retain from all these definitions the fact that they evoke "what individuals do and how they do it". However, we adopt the definition given by Sensevy and Mercier which remains the most functional for us. In a comparative approach to didactics, these authors define practice using the notion of "didactic action", i.e. "what individuals do in places (institutions) where they teach and learn", considering that this action is carried out jointly by the teacher and his students [12].

Indeed, in our study we use the notion of "classroom practices" rather than "teaching practices" or "teaching practices" since we consider the classroom as a system and the way in which this system operates influences student learning. However, evaluation is a very important area of research, it is one of the most important aspects of learning, it must be used to promote and analyze student learning, and it is essential in this process to see the progress and effectiveness of the methods used, so evaluation is an integral part of the teaching-learning process [13]. In looking at teaching practices, we have chosen to focus on evaluation, since evaluation is an essential factor in learning. Effective teachers use evaluation as a tool to motivate students. Effective teachers use assessment as a tool for motivating students. They do not use evaluation as a sanction or control only, but as an essential element to regulate teaching and learning issue.

The purpose of this research is to evaluate the practices adopted by teachers in a teaching-learning situation in order to ensure a good quality of teaching in Morocco.

\section{Methodology}

In order to evaluate the practices adopted by teachers in a teaching and learning situation to ensure a good quality of teaching in Morocco, we conducted an exploratory survey to highlight 11 items declared the most important by the teacher training system and in the conduct of their professional activity through a survey for 50 teachers of physical - chemistry science at the qualifying cycle of 10 
public schools in Kenitra during the school year 2019-2020.

Our sample of 50 teachers is chosen at random.

This survey, contains some practices and consists of customizing the rate of their use in the class, practices mentioned in the survey are:

- The use of learning theories (Behaviorism, Cognitivism, Socio-constructivism, Constructivism, Jachtalti);

- Planning and use of contents (use of pedagogical sheets and textbooks when preparing course contents, basing oneself on pedagogical orientations and the reference framework);

- The use of pedagogical and didactic strategies (new pedagogical approaches, effective use of different teaching resources and related strategies to explain and model the concepts and skills specific to each subject, use of experimental activities);

- Communication and Interpersonal Relations (Create a safe learning environment where students respectfully express their opinions and participate fully in the learning process);
The use of different teaching styles (Transmitting Style, Pushing Style, Permissive Style, Questioning Style, Active Style, Guided Style);

- Teaching aids: Audio-visual aids, Computer aids, written documents, experimental materials;

- Teaching methods: The inductive approach, the deductive approach, the hypothetico-deductive approach;

- Teaching strategies (Direct, Indirect, Interactive, Experimental);

Evaluation methods (Diagnostic, Formative, Summative).

\section{Results}

\section{1) Teaching practice related to the dimension of the pedagogical and didactic strategy:}

- Presentation of the results:

According to the analysis of the grids returned by the teachers we found:

Table 1. Results of the practices used by the teachers at the classroom level

\begin{tabular}{|c|c|c|c|c|c|}
\hline & & $\mathbf{N}$ & $\mathbf{O}$ & $\mathbf{S}$ & $\mathbf{A}$ \\
\hline $\begin{array}{l}\text { LEARNING } \\
\text { THEORIES }\end{array}$ & Behaviorisme & & $30 \%$ & $30 \%$ & $40 \%$ \\
\hline \multirow{8}{*}{$\begin{array}{l}\text { CONTENT PLANNING } \\
\text { AND EXPLOITATION }\end{array}$} & Usage of Textbook and content organization & & $20 \%$ & $20 \%$ & $60 \%$ \\
\hline & $\begin{array}{l}\text { basing on the pedagogical orientations and referential } \\
\text { framework }\end{array}$ & & $20 \%$ & $20 \%$ & $60 \%$ \\
\hline & Usage of new pedagogical approaches in teaching & & $30 \%$ & $30 \%$ & $40 \%$ \\
\hline & $\begin{array}{l}\text { Integrating new information and communication } \\
\text { technologies }\end{array}$ & & $50 \%$ & $30 \%$ & $20 \%$ \\
\hline & $\begin{array}{c}\text { Encourage students to reflect and clarify their ideas by } \\
\text { asking probing questions and putting them into problem } \\
\text { situations. }\end{array}$ & & $30 \%$ & $30 \%$ & $40 \%$ \\
\hline & $\begin{array}{l}\text { Create a safe learning environment where students } \\
\text { respectfully express their opinions and participate fully in the } \\
\text { learning process. }\end{array}$ & & & $40 \%$ & $60 \%$ \\
\hline & Communicate in a tolerant manner away from violence & & $20 \%$ & & $80 \%$ \\
\hline & Use and diversify languages & & $20 \%$ & $40 \%$ & $40 \%$ \\
\hline \multirow{3}{*}{ TEACHING STYLES } & Transmissive style (more focused on material) & & $30 \%$ & $50 \%$ & $20 \%$ \\
\hline & Incentive style (both subject-centered and learner-centered) & & $30 \%$ & $30 \%$ & $40 \%$ \\
\hline & Permissive style (very little learner or subject-centered) & & $30 \%$ & $50 \%$ & $20 \%$ \\
\hline \multirow{2}{*}{$\begin{array}{l}\text { PEDAGOGICAL } \\
\text { MEANS }\end{array}$} & Audio-visual means & & $10 \%$ & $60 \%$ & $30 \%$ \\
\hline & $\begin{array}{l}\text { The hypothetico-deductive approach (consists in making } \\
\text { hypotheses) }\end{array}$ & & $10 \%$ & $10 \%$ & $80 \%$ \\
\hline
\end{tabular}


- Interpretation of results:

According to the analysis of the results received by the teachers we can see:

$40 \%$ of the teachers evaluated always use behaviorism as a learning theory, while $30 \%$ of them use it sometimes and $30 \%$ use it often, for textbooks and content organization in the planning and exploitation of contents $60 \%$ of the teachers always use it, while only $20 \%$ of them use it sometimes and $20 \%$ use it often, for the second tool of planning and exploitation of contents we find that $60 \%$ of the teachers always base themselves on the pedagogical orientations and also the referential framework in the teaching and learning process, while $20 \%$ of them use it sometimes and $20 \%$ use it often, for the new pedagogical approaches that consider themselves as one of the necessary measures of planning in teaching $40 \%$ of teachers always use them, $30 \%$ of them sometimes use them and $30 \%$ often use them too, for the new information and communication technologies that are becoming the trend in the teaching and learning process $20 \%$ of teachers always integrate them in teaching, while $30 \%$ of them use them sometimes and also $50 \%$ use them often, $40 \%$ of the teachers encourage their students to reflect by asking in-depth questions and putting them in problem situations the new pedagogical approaches in teaching always ,30\% of them use them sometimes and also $30 \%$ use them often. In content planning $60 \%$ of the teachers always create a safe learning environment where students respectfully express their opinions and fully participate in the learning process, while $40 \%$ of them use it sometimes. For the teacher-student interaction and communication side, we find that $80 \%$ of the teachers always communicate with the learners in a tolerant way away from violence, while $20 \%$ among them use this way often. For the part of language diversity $40 \%$ of the teachers use diverse languages always in the classroom, while $40 \%$ use them sometimes and $20 \%$ of them use them frequently. In the part of teaching styles $20 \%$ of the teachers always use the transmissive style as a teaching style, while 50\% also use them sometimes $30 \%$ among them use this way often. $40 \%$ of the teachers

always use the incentive style, $30 \%$ among them use them sometimes while the remaining $30 \%$ use this style often. $20 \%$ of teachers always use the permissive style, $50 \%$ also use it sometimes $30 \%$ of them use it often. For the use of audio-visual means as one of the pedagogical means in the process of teaching and learning $30 \%$ of the teachers always use them, $60 \%$ of them use them sometimes while the remaining $10 \%$ use them often. For the hypothetico-deductive approach $80 \%$ of the teachers always use them, while $10 \%$ of the teachers sometimes use them $10 \%$ of the remaining $10 \%$ use them often.

\section{2) Practice Related to the Learning Evaluation Dimension}

Evaluation Modes
- Presentation of the results:

Table 2. Results of the evaluation modes

\begin{tabular}{|c|c|c|c|c|c|}
\hline & & $\mathrm{N}$ & $\mathrm{O}$ & $S$ & A \\
\hline \multirow{3}{*}{$\begin{array}{l}\text { Evaluation } \\
\text { Modes }\end{array}$} & $\begin{array}{l}\text { Diagnostic } \\
\text { Evaluation }\end{array}$ & & & $20 \%$ & $80 \%$ \\
\hline & $\begin{array}{l}\text { Formative } \\
\text { Evaluation }\end{array}$ & & & & $100 \%$ \\
\hline & $\begin{array}{l}\text { Summative } \\
\text { Evaluation }\end{array}$ & & & & $100 \%$ \\
\hline
\end{tabular}

- Interpretation of results:

According to the analysis of the results we notice that: $80 \%$ of the teachers always use the diagnostic evaluation, while the remaining $20 \%$ sometimes use it. For the second mode of evaluation: Formative evaluation $100 \%$ of teachers always uses it. Same thing for the summative evaluation $100 \%$ of teachers always use it

\section{Discussion}

In general, the methodological approaches used to study teaching practices are based on the collection of direct, representational information, based on more or less consistent samples [13]. In concrete terms, most research on teaching practices is based on the results of survey analysis carried out with substantial samples of participants [14].

We consider that teaching "means putting in place didactic, pedagogical, material, temporal, relational and active situations likely to promote learning" [15] with an essential element which is to propose a task to be accomplished by the students. Teaching is therefore not only about transmitting (declarative) knowledge, but also about setting up situations that should enable students to build (procedural) knowledge and skills.

The step of planning and exploitation of contents is considered as one of the necessary elements of the teaching-learning process, which contains several steps.

The integration of new information and communication technologies is one of these necessary tools in the Moroccan education system, the use of TIC in the act of teaching and learning in Morocco shows a slow place in school practices and it is also limited for some schools and for some disciplines As specified (Maouni et al, 2014; El Ouidadi, 2011) [16].

According to the results received we can see that $20 \%$ of teachers always integrate TIC in teaching, while $30 \%$ of them sometimes use them and also $50 \%$ often use them. In France, according to a 2008 survey by the Ministry of National Education, 64\% of secondary school teachers use ICTs. In 2011, according to the Profetic survey of the French Ministry of Education, 77\% of teachers use ICT with their students, including at least once a week (MEN-PROFETIC, 2011) [17].

During the discussions conducted during this study, the 
majority of teachers said that they find obstacles to the integration of TIC in the classroom, especially at the level of software use; the preparation of animations and presentations, they have linked these obstacles by the lack of supervision in the use and application of TIC, they have just benefited from a short training which they discovered the new term with its basic concepts on the one hand, on the other hand, the discussions also show that teachers are faced with insufficient computer equipment. In Africa, the main obstacle encountered in the use of TIC in education is the lack of software, computers, electricity, etc. (Karsenti, Salomon Tchameni NGAMO, 2009). In other words, most African countries face limited access to these technologies due to the high cost of installation, use and maintenance of the necessary infrastructure.

The integration of TIC in schools requires first of all the installation of materials and equipment. Indeed, for pedagogical integration of these technologies in the classroom, teachers need a full range of educational software and content, easily accessible online information on the subject matter, and depend on the level of difficulty and ease of use of the materials (OECD, 2001) [18].

According to François-Marie GÉRARD and Xavier ROEGIERS (2009), "a textbook can be defined as a printed tool, intentionally structured to be part of a learning process in order to improve its effectiveness" [19].

The school textbook presents a clear and defined vision of the teaching-learning process; it helps the teacher and the learner to position them in relation to this process in terms of measuring the know-how of the teacher and the learner. The answers received show that the majority of teachers $(60 \%)$ always use the textbook because it facilitates the organizational phases, On the other hand, the textbook helps to build an autonomous learner capable of preparing, revising and doing homework at home through the knowledge of what he is learning and what he will have to learn afterwards.

A survey conducted by Nyssen in 1998 among 800 teachers in the French Community of Belgium (Demeuse \& Monseur, 2000) showed that a small percentage of teachers used textbooks in science [20]. Although this percentage increased significantly over the years of study, it remained low $(7 \%)$ in all years. If we take the data available from Adeb (Association of Belgian Publishers), we can see that the turnover of school publishing began to decrease from 1975 and only resumed an increasing trend in 2002 (Conseil du livre, 2008, p. 6).

The situation of the education system and languages (including Arabic) is described as alarming by several reports such as those of the World Bank, the Cinquantenaire, the Higher Education Council, etc., and by the Royal Speech of 20 August 2013. "(MESSAOUDI, 2015, p. 74) [21].

For the first time in Morocco's history within the framework of the "strategic vision 2015-2030", it's a fairly clear vision regarding the status of languages in the education system by attempting to establish "a new linguistic architecture based on plurilingualism and the alternation of languages" (Conseil Supérieur de l'Education, 2015, p. 50). [22].

According to the debate granted by the concerned institutes on the teaching of scientific subjects in French, it was decided to insert the point the use of diverse languages in the classroom as a tool for planning and exploitation of contents, and according to the results received we see that: $40 \%$ of teachers always and sometimes use diverse languages, on the other hand $20 \%$ often use them.

Parallel conversations with the same teachers state that the fact of using different languages in the classroom depends on the level of comprehension of the learner and also on the situation being taught, sometimes they find themselves obliged to explain one of the phenomena with the mother tongue (DARIJA) instead of using classical Arabic or French due to the low level of the learners in this subject.

Studies show that nearly $40 \%$ of children do not have access to education in a language they understand, which has negative consequences for their learning (UNESCO, 2016) [23]. Many countries still give priority to national or official languages (second language) as a medium of instruction, even though children often do not speak them at home (Kosonen, 2017). [23] The results of learning assessments show that when the languages spoken at home and at school are not the same, performance is affected (UNESCO, 2016). The use of the mother tongue in the classroom has been shown to improve student participation, reduce attrition and increase the likelihood of family and community involvement in the child's learning (Trudell, 2016) [23]. In order to improve learning, students also need culturally sensitive and inclusive programs, as well as learning materials in a language they know (Bühmann \& Trudell, 2007; Mackenzie \& Walker, no date; Pinnock, 2009b; UNESCO, 2016) [23].

Most studies now agree that students' learning outcomes are much better when they are taught in their mother tongue for at least the first six years of elementary school, before the introduction of the second language, which becomes the main language of instruction (Ball, 2011; Benson, 2004; Pinnock, 2009a, 2009b; UNESCO, 2016) [23]. Research shows that bilingual and/or multilingual education enhances students' confidence and self-esteem (UNESCO, 2016) [23].

In bilingual models, students use both their mother tongue and second language in a variety of subjects throughout primary and secondary school (Ball, 2011; Pinnock, 2009a) [23].

Evaluation would therefore consist of identifying these practices in a teacher's actions in order to qualify his or her performance, or even to identify these skills.

Evaluation of student learning is an integral part of the teaching/learning process. During the course of his or her 
learning, the student is led to go through different forms of evaluation in order to verify whether the defined teaching objectives have been achieved, According to the answers received, $100 \%$ of the teachers always use the Formative Evaluation as a tool to regulate the learning of the students through the results obtained in the exam, same thing for the Summative Evaluation $100 \%$ of the teachers also always use it as a means to allow the student to verify if he has reached the set objectives and to position himself in relation to the class

An evaluation survey was available on the School Education Gateway from February 19 to March 25, 2018, with a total of 534 responses. The survey showed that teachers use both summative in-class evaluation $(87 \%$ of respondents) and formative in-class evaluation (72\%). However, most of the assessment methods they use are teacher-centred and focused on teacher-directed actions, as opposed to more student-centred approaches such as peer and self-assessment.

The evaluation of the practices adopted by the teachers can be carried out to personalize the level and the gaps of the students, to form judgments, to make decisions, to know the results, to develop new knowledge, to reinforce the capacities in response to the needs of the learners and also to personalize the weak and strong points of the teachers in order to adopt practices that allow them to ensure a good quality of teaching.

According to the analysis of the results obtained, we can see that the practices are numerous and its uses differ from one teacher to another depending on the situation experienced in the classroom, which allows the teacher to select effective and appropriate practices to achieve each effect, in order to regulate the learning of students, improve their levels and evolve the teaching and learning process, in fact, the evaluation plays a role in regulating practices and learning.

The results received reveal the fact that practices differ from one teacher to another according to several factors (situation in the classroom, seniority or training). Unfortunately, teachers who make sense in the research are not trained and supervised adequately, even if in their speeches teachers continue to confront old practices.

One of the important observations that we were able to note through the results we received was the lack of training and supervision, as well as the failure to respect the criteria concerning the necessary documents (pedagogical orientations for example).

Other researchers highlight the great variability of practices within a single teacher and doubt that the aggregation of multiple good practices necessarily produces effectiveness [24].

\section{Conclusion}

The objective of this research was to measure the pedagogical practices adopted by teachers and to understand the determinants that influence or hinder these innovations among secondary school teachers in Morocco. The methodology used is a survey based on two questionnaires for teachers. Our sample of 50 teachers who are covering 10 schools in the province of Kenitra is chosen at random. The results show that most of the teachers have a low level of innovation in the organization of the classroom $(60 \%)$, in the use of ICT $(20 \%)$, in the use of textbooks $(60 \%)$ and in the use of pedagogical approaches $(40 \%)$. The creation of a safe learning environment makes students respectfully express their opinions and fully participate in the learning process and also communicate in a tolerant manner high among teachers, $60 \%$ and $80 \%$ respectively.

Regarding innovation in methods of using assessments $80 \%$ of teachers always use diagnostic assessment, $100 \%$ of teachers always use formative and summative assessment. The results show that teachers' pedagogical innovations differ according to the characteristics of teachers, classes and schools. These differences are related to the context in which the teacher evolves (teachers belong to schools which themselves belong to regions).

The evaluation of teaching practices offers teachers the opportunity to find answers to pedagogical and didactic questions that are problematic for them, on the one hand, and allows them to regulate their practices according to the needs of learners in order to ensure a good quality of teaching and learning, on the other hand, so evaluation is one of the essential components of teaching practices.

\section{REFERENCES}

[1] Bressoux, P. (2002). Contribution to the analysis of teacher effect and class practices. In J. Fijalkow \& T. (2002). Nault (Eds.), La gestion de la classe (pp. 199-214). Brussels Belgium: De Boeck.

[2] Bru, M. (2002). Pratiques enseignantes : des recherches à conforter et à développer. Revue française de pédagogie, $138,63-73$.

[3] Bru, M. and Talbot, L. (2001). Les pratiques enseignantes : une visée, des regards. In M. Bru and J.-J. Maurice (Eds.), Les pratiques enseignantes: contributions plurielles (pp. 9-34). Toulouse, France: Presses universitaires du Mirail.

[4] Martineau, S. and Presseau, A. (2011). Savoirs et pratiques dans une communauté autochtone. In P. Maubant (Ed.), Enjeux de la place des savoirs dans les pratiques éducatives en contexte scolaire: compréhension de l'acte d'enseignement et défis pour la formation professionnelle des enseignants (p. 157-192). Quebec City, Quebec: Presses de l'Université du Québec.

[5] Reuter, Y., Cohen-Azria, C., Daunay, B., Delcambre, I. and Lahan ier-Reuter, D. (2013). - Dictionnaire des concepts fondamentaux des didactiques (3rd ed.). Brussels, Belgium: De Boeck. 
[6] Yvon, F. and Saussez, F. (2010). Analyzing teaching activity. Methodological and theoretical tools for intervention and training. Quebec: Presses de l'Université Laval.

[7] Altet, M. (2002). Une démarche de recherche sur la pratique enseignante: l'analyse plurielle. Revue française de pédagogie, 138, SS-93.

[8] Chantal MARTINEZ "Pratiques enseignantes et expérience professionnelle antérieure", Thèse en vue de l'obtention du diplôme de Doctorat Spécialité : Sciences de l'Éducation, 12 mai 2018, page 54.

[9] Marcel, J.-F. (2004). Contextualized research and teaching practices. In J.-F.

[10] Altet, M. (2009). Preparation and planning. In J. Houssaye and Y. Abernot (dir.), La pédagogie : une encyclopédie pour aujourd'hui (Se éd. p. 77-SS). Issy-les-Moulineaux, France: ESF éditeur.

[11] Dessus, P. (2000). La planification de séquences d'enseignement, objet de description ou de prescription ? Revue française de pédagogie, 133, 101- 116.

[12] ALTET, M. (2002). Une démarche de recherche sur la pratique enseignante : l'analyse plurielle. Revue Française de pédagogie, 138, 85- 92. January, February, March, 2002.

[13] Barbier R., 2000, " Le formateur d'adulte comme homme à venir ", Revue Mémoires du XXIème siècle, Paris, Editions du Rocher.

[14] Sensevy G. \& Mercier A. (dir.). Agir ensemble : l'action didactique conjointe du professeur et des élèves Rennes : PUR, 2007. - - 225 p. (Paideai).

[15] Scal1on, Gérald. 2004. L'évaluation des apprentissages dans une approche par compétences. Saint-Laurent (Qq: Éditions du Renouveau pédagogique inc. 342 pages.

[16] Cook, T. D. (2002). Randomized Experiments in Educational Policy Research: A Critical Examination of the Reasons the Educational Evaluation Community has Offered for not Doing Them. Educational Evaluation and Policy Analysis, 24(3), 175-199.

[17] Larose, F., Grenon, V., Bédard, J., \& Bom-que, J. (2009). Analyse des pratiques enseignantes et la construction d'un référentiel de compétences : perspectives et contraintes méthodologiques. Nouveaux cahiers de la recherche en éducation, $12,65-82$.

[18] Bru, M. (2001). Étudier les pratiques enseignantes : les raisons d'un choix, Les Dossiers des Sciences de l'Éducation, (5), 5-7. Here we are clearly positioned in constructivist and socio-constructivist perspectives.

[19] Maouni A., Mimet A., khaddor M., Madrane M., Moumene M.: L'intégration des TIC dans l'enseignement des SVT au Maroc : réalité et attentes. RADISMA, No. 10, January 27. 2014.

[20] OECD (2001). Rapport annuel. Paris: OECD PUBLICATION. Online] http://www.oecd.org/dataoecd/49 /34/1911915.pdf

[21] PROFETIC survey: among 5,000 secondary school teachers. Ministry of National Education, Youth and Community Life. 2011

[22] Gérard, F.-M and Roegiers X., 2009, Des manuels scolaires pour apprendre - Concevoir, évaluer, utiliser, Brussels, De Boeck University.

[23] [DEMEUSE and MONSEUR 00] Demeuse, M. and Monseur, Ch. (2000). Policy and use of textbooks in mathematics and science. Cahiers du Service de Pédagogie expérimentale, 3-4, 177-183.

[24] MESSAOUDI, L. (2015). La fracture linguistique dans l'enseignement scientifique au Maroc quelles remédiations. Revue Langues, cultures et sociétés, Volume 2, ${ }^{\circ} 1$, June 2016.

[25] Conseil Supérieur de l'Education, de la Formation et la Recherche Scientifique. Analytical report. Pour une École de l'équité et de l'égalité des chances. Strategic Vision of the Reform 2015-2030

[26] UNESCO Bangkok Office and Regional Office for Education in Asia and the Pacific. 2020. Tools for planning and monitoring programmes of multilingual education in Asia. Bangkok: UNESCO Office Bangkok.

[27] Bru, M. (2002). Pratiques enseignantes : des recherches à conforter et à développer. Revue française de pédagogie(138), 63-73. 